проф. др Урош Дојчиновић*

Факултете савремених уметности

Београд
930.85:78(51)

https://doi.org/10.18485/melissa.2018.17.1.ch7

Оригинални научни рад

Примљен: 01.08.2018

Прихваћен: 11.09.2018.

\title{
МУЗИКА НА ПУТУ СВИЛЕ
}

\section{Сажетак}

Музика се као једна од најистакнутијих хуманистичка наука, у којој неспорно доминирају уметничке сфере, истиче и својим врло егзактним странама, чија се мултидисциплинарна тежишта налазе у великом броју других природних и друштвених наука. Од њеног првог настанка у праскозорје људске цивилизације, стасавала је, развијала се и на глобалном нивоу ширила, полазећи управо из колевки старих источних цивилизација. На тој еволутивној линији, која ће касније постати симболична попречића између Истока и Запада, најстарије и најудаљеније полазне тачке (око 3500 до 3000 година пре наше ере) свакако је била Кина, а затим и друге земље Блиског истока. Као и мноштво других цивилизацијских тековина и музика се с простора Медитерана потом прелила на европско тло. Можемо рећи да је од почетка била у нераскидивим везама са свеукупним културним развојем друштвених заједница, пружајући изузетна упоришта религијским, филозофским, књижевним и свеколиким другим људским спознајама, промишљањима и закључивањима. Праћење појединих теоретских и практичних аспеката одређених музичких инструмената, као што су трзалачки кордофони, изузетно су подесни за аналитичка разматрања у контексту Пута свиле, те јединствене метафоре за трасферзалне везе између Источне Азије и Средоземња.

Кључне речи: Музика, Трзалачки кордофони, Кина, Медитеран, Европа.

У оквиру музичке уметности омогућено је континуирано праћење еволутивног процеса музичких инструмената, од њиховог зачетка и првих историјских трагова до савременог тренутка. Неоповргунто је становиште да су полазне тачке данас свих врхунски усавршених и на глобалном нивоу раширени музичких инструмена-

Факултет савремених уметности, Светозара Милетића 12, Београд 11108

urosdojcinovic@eunet.rs 
та, прапостојбине старих цивилизација на афричком и азијском простору. У овом случају пажњу усредсређујемо на трзалачке жичане инструменте, тј. трзалачке кордофоне, код којих се лако запажа јасно поклапање њиховог историјског пута са такозваним Путем свиле. Посебно значајна је маршута чији се један крај протеже од древне Кине у источној Азији, прелази и пролази кроз више других земаља Средњег и Блиског истока, да би током античког периода с простора Медитерана прелио и на европско тло. Мањег значаја имале су копнене везе између Кине и Европе, које су такође од најстаријег периода омогућавале различиту трговинску размену и дипломатске контакте. Међутим, проток музике овим изузетно широким подручјима, чије је прелажење изискивало много времена и било скопчано са различитим реметилачким факторима, имао је знатно мање ипликација на свеукупан развој трзалачких кордофона.

Пре разматрања најстаријих трзалачких жичаних инструмената старог века у Кини - једној од њихових колевки, треба подсетити да су се први праоблици кордофона појавили далеко раније, у праскозорје људске цицвилизације, захваљујући ловачком (тј. музичком) луку палеолитских ловаца. Протекло је потом неколико десетина миленијума до формирања других бројних, разноврсних и савршенијих инструмената, познатих у музичким праксама старих источних цивилизација. ${ }^{1}$ Њихова онтогенеза је текла у складу са свакодашњим човековим потребама и његовим општим културним развојем, пратећи све пролазне стадијуме, од првобитне примитивне заједнице, до раног робовласничког друштва.

Просторно, најзначајнији део ових дешавања обухватио је пре свега широке потезе западне Азије и источног Медитерана. Треба имати на уму да су се током последњих десетак хиљада година

1 Раздобље старог века карактеришу и врло изражене музичке праксе народа чије су културе биле на вишем нивоу; у употреби су им били врло богати репертоари трзалачких кордофона. По свом облику, величини и конструкцији, многобројни варијетети харфи, лира и лута, били су комплексније грађе и имали су посебно важну улогу у свакодневном животу људи старих цивилизација попут Месопотамије, Египта, Персије, затим арапског, јеврејског и других народа Блиског и Средњег истока. И ове земље сматрамо својеврсним колевкама музичке културе, које су били први расадници трзалачких жичаних инструмената, одакле ће се они пренети на југоисточно европско тле. 
на земљи значајно мењали климатски услови, а са њима и начини људског живота. Почетна номадска лутања замењена су ратарским пословима и животом у сталним насеобинама. Тако средином четвртог миленијума пре нове ере у Евроазији ничу прве цивилизације, означавајући симболички почетак нове фазе у историји света и његове културе и уметности. Настају одвојено и самостално али са доста сродних елемената. То су робовласничке средине, које се често формирају у плодним равницама речних токова, са дефинисаним сталежима и развијеном поделом рада. У њима уметност поприма класно обележје. ${ }^{2}$ Музика се дели на ону намењену владајућим круговима и ону којом се баве потлачени слојеви (шире народне масе). Познавање музичке вештине се стиче као резултат процеса учења, а њега ће врло брзо окарактерисати и појава професионализма у овом послу. Са развитком свести о друштвеном значају уметничке делатности и музике као значајног чиниоца у животу, те улоге самог музичара појединца - као мајстора свог заната, полако се обликују и различите стилске школе, критичко музичко мишљење, али и основе свих других теоријских и естетских разматрања у овој области.

Када је реч о Кини, једној од прапостојбина и полазишта разматраних музичких инструмената, пажњу усмеравамо на оне трзалачке кордофоне који су својом грађом и обликом сродни лаутама и гитарама, изразитим представницима ове групе инструмената. Уз доминацију у тадашњој кинеској музичкој пракси, а захваљујући својим морфолошким карактеристикама, они представљају важне карике еволутивног ланца наших савремених трзалачких кордофона. Њихова употреба претходила је античкој музичкој уметности у Европи, а са осталим инструметима старих источних цивилизација значајно су утицали на формирање средњевековног јеврејског и арапског музичког инструметаријума који је допринео развоју европског. Почеци историјске размене са кинеском музичком културом поклапају се са развијањем трговинских односа кинеске царске династије Хан са античким римским царством. Већ од

2 У овом периоду развијају се архитектура, књижевност и ликовна уметност, а од посебног је значаја и откривање различитих знаковних система и ликовних форми, које представљају прве писма и омогућавају бележење и записивање историјских дешавања, као и културних и музичких догађаја. 
првих посета римских изасланика кинсеким дворовима, па током целог средњег века и надаље, дипломатске и трговинске везе које су завршавале на источном крау пута свиле, омогућиле су и контакте са културом и музиком древне Кине. Не мали број путописних белешки и докумена управо подробно сведоче о томе.

Сам однос Кинеза према музици, коју су чврсто везивали за филозофију природе на којој су темељили религију, понајбоље је осликан у делу једног од њихових најстаријих музичких писца из 3. века: Лу Пу-Be (Lü Pu-We) сматра да се о музици може разговарарти само са оним човеком, који разуме смисао света. Сличне ставове налазимо и у делима Шу Чинга Књига историје и Ли Чи-јевој Историји обреда. По првом, музика прави хармонију између људи и духова, док је за другог музика та која изражава склад између неба и земље. Симболика бројева и њихов узајамни однос, какав постоји код појединих интервала (нпр. квинта), у уској су корелацији са музиком. Она има важно место и у моралном васпитању, какво ћемо вековима касније наћи и код античких Грка.

Најстарији сачувани примерци кинеских музичких инструмената потичу из времена династије Чанг, када под окриљем царских дворова налазимо већ формиране велике оркестре. У току наредних неколико династија биће успостављена тачна - апсолутна висина тона, као и тонални систем базиран на квинтном кругу (пентатонска лествица); започеће контролисана музичка пракса и архивирање народних мелодија. Треба подсетити и да је кинесеко нотно писмо старије од 2000 година.

Бројни музички инструменти у Кини били су подељени у осам pa-jin категорија, у зависности од материјала од кога су направљени: метал, камен, глина, кожа, свила, дрво, тиква и бамбус. И ова подела иницирана је ра-кua филозофским гледиштем, које третира тих осам симболичких категорија насталих комбиновањем супродстављених принципа jang и jin. За нас су посебно значајни инструменти са тзв. свиленим струнама, који припадају петој групи. Међу њима најстарије су кинеске цитре $k^{\prime}$ in и šе код којих је варирао број жица; најпре их је било 5, затим 7, а касније и до 50. Под најдубљом мелодијском струном постављени су прагови. Свирање на овом инструменту зах- 
тевало је сложену извођачку технику, која је подразумевала употребу посебних звучних ефеката као што су 26 врста вибрата, затим глисанда и др. Инструмент $k^{\prime}$ in је истовремено сматран култним предметом Кине са посебним религијским симболизмом.

Друга два трзалачка кордофона су мала лаута крушколиког корпуса p'ip'a, са четири свилене струне, пореклом из западне Азије, коју и данас можемо срести у музичкој пракси, и san-hjen лаута са три струне, натегнуте преко дрвеног звучног резонатора, пресвученог са обе стране змијском кожом. Навешћемо још и kung-hou врсту харфе персијског порекла, која је такође одомаћена у кинскеој музичкој пракси, а додатно сведочи у прилог узајамних музичких утицаја.

Beћ је назначено да за време античког периода музика прелази на европски простор. Она је и даље неодвојив пратилац целокупног културног развоја друштвене заједнице, повезана са осталим етнолошким, социолошким, психолошким и другим факторима, чиме пружа изузетно упориште различитим религијским, филозофским, књижевним и свеколиким другим људским промишљањима и спознајама. Позиција и улога музике тог раздобља потврђена је богатом релевантном грађом, коју чине археолошки извори, писани и ликовни документи, као и сачувани примерци античких грчких композиција, њихових музичких расправа и теоретских трактата, али и аутентичних инструмената.

Пратећи Пут свиле, као јединствене метафоре за трасферзалне везе између Источне Азије и Средоземља, попут многих других цивилизацијских тековина, тада већ видно издиференциран музички инструментаријум, се са истока проширио према Европи. Захваљујући најпре античког Грчкој, а нешто касније и Риму, он ће брзо запосести остатак европског континента. Трзалачки кордофони, сада већ довиљно развијени у облицима као што су античке лире, кumape и харфре, затим различите врсте оријенталних инструмената из породице лаута и тамбура, продрли су у све делове Европе, паралено пратећи даљи генерални развој и експанзију музичке уметности у целини. Посебне заслуге за ову дисперзију трзалачких кордофона свакако припадају великој римској империји, која је простирући се широким подручјем Југоисточне Европе, са својим музичким наслеђем 
утемељеним на грчким узорима, имала посредну улогу у ширењу инструмената и премошћавању античке и хришћанске музике.

Ако би се осврнули на одређене теоретске и практичне аспекте трзалачких кордофона, иначе због своје популарности и распорострањености изузетно подесне за аналитичка разматрања, лако би потврдили да је на овој маршути сматраној симболичном попречицом између Истока и Запада, и раздобље интензивног мешања народа на Балкану током средњег века, за њих било посебно плодоносно. ${ }^{3}$ Бројни учесници у музичкој пракси на тлу Југоисточне Европе доносили су своје аутохтоне жичане инструменте; они су прихватани, устоличавани и сходно домаћој пракси брзо модификовани и уграђивани у традиционалне музичке миљее. Илустроваћемо ово само констатацијом да и данас значајан део балканског народног фолклора почива на различитим варијететима тамбурашких инструмената, који нису аутохтона творевина овог простора, али су временом толико срасли са овдашњим традиционалним елементима да су постали нераскидив део народног музичког израза. ${ }^{4}$ На другој страни, срећемо различите врсте гитара, данас изузетно популарних и свеприсутних кордофона. И њихов долазак и присуство током средњевековног раздобља било је нарочито подстакнуто арапским освајачима Маварима, затим проласцима крсташких ратника преко балканских територија, трговачким везама Истока са западним центрима, делатношћу путујућих музичких извођача и забављача и сл. ${ }^{5}$

3 Како значајан део музичке културе Балкана почива на античким традицијама, такође и корени органографије репертоара његових трзалачких кордофона потичу из истих извора, утемељаваних на инструментима старих источних народа. Вишевековне миграторне појаве које су се непрекидно одвијале, а њихово присуство је чак и данас уочљиво, са историјско-музичког становшта, могуће је поделити на три периодне целине: најпре средњевековни период (од краја 15. века), затим раздобље од 15. до 18. века и најзад од 18. до прве половине 20. века. Током свих њих константно је на балканксом простору присутно биполарног сучељавање културних утицаја Истока и Запада.

4 Подсетимо турско присуство на Балкану обележено је између осталог и доминацијом тамбуре као једног од сродних трзалачких жичаних инструмената.

5 Колико су средњевековне везе оријенте са југозападним европским градовима, допринеле ширењу лауте и гитаре најпре у медитеранском појасу, а затим и северним деловима, њихово дефинитивно устоличење свакако су завршиле најезде исламизованих арапских освајача из северозападне Африке на Пиринејско полуострво; Шпанија коју су запосели постала је један од главних жаришта ових инструмената и основно полазиште њиховог даљег ширења. 
У целини, треба нагласити да су за трзалачке кордофоне у Европи пресудну улогу одиграле управо поморске везе преко Средоземља, у тренутку када је међуконтинетална размена интензивирана напредовањем и ширењем поморског саобрађаја, почетком новог доба. Овакав вид путовања до источне Азије и назад, омогућио је далеко бржу, сигурнију и живљу трговину и комуникацију. Бродовима нису преношена само техничка достигнућа и потрошна роба, већ су размењивани религијски и идеолошки погледи, филозофска становишта и култура. Наравно, известан допринос у преношењу музичке праксе и инструментаријума направљен је и копненим путевима, нарочито током 13. века, и то посредством монголских продора у Европу. ${ }^{6}$ Међутим, номадски начин живота, најчешће ратничко-освајачке активностим и непрестане миграције, нису погодовале озбиљнијој и организованијој музичкој пракси, каква се неговала у организованим земљама попут древне Кине, али и неких других старих културних цивилизација на простору Средњег и Блиског истока.

\section{Prof. Dr. Uroš Dojčinović}

\section{MUSIC ON THE SILK ROAD}

\section{Summary}

Music, as one of the most prominent humanistic sciences, in which undoubtedly dominates art spheres, also points out to its very exact sides, whose multidisciplinary issues lie in many other Exact and Cocial Cciences. Since its first creation in the early dawn of human civilization, it has grown, developed and expanded on a global scale, starting from the cradle of ancient Eastern civilizations. On this evolutionary line, which will later become symbolic route between the East and the West, the oldest and furthest points of the music departure (about 3500 to 3000 years before our era) was certainly China,

6 Познати су једноставнији типови трзалачких кордофона - типа лауте, који су сретани у поседу монголских племена. 
and then those other countries of the Middle East. Like with many other civilization achievements, music has also passed from the Mediterranean region to the European soil. We can say that from the beginning it has been inextricably linked with the overall cultural developments of the it has been inextricably linked with the overall cultural developments of the human community, providing exceptional support for religious, philosophical, literary and all other human knowledge, thoughts and conclusions. Monitoring of some theoretical and practical aspects of certain musical instruments, such as plucked cordophones, is extremely suitable for analytical considerations in the context of the Silk Road, and the unique metaphor for trasferal links between East Asia and the Mediterranean.

Key words: Music, Plucked string instruments, China, Mediterranean, Europe. 